\title{
INTERAKSI DI KELAS PERSPEKTIF PENDEKATAN KONSTRUKTIVISTIK UNTUK PENGEMBANGAN AKHLAK
}

\author{
Hanun Asrohah \\ (Fakultas Tarbiyah UIN Sunan Ampel Surabaya \\ Email: asrohah@yahoo.com)
}

Abstract: Morality and human behavior are created as social construction, and developed through education. This article is aimed at explaining about interactions amongst students in the classroom, based on constructivist learning theory, as source of positive atmospheres that are very important for the formation of character and morality. Morality is not simply taught or absorbed in subjects like civics or social studies. It must be developed in a variety of activities in the classroom. According to the theory, developing a good and appropriate atmosphere is necessary to introduce good values and norms in which students learn to construct their own knowledge through continuous interactions with social contexts, and develop their ideas and feelings about people and objects. They can learn about life critically and understand how people live and under what condition they live, whether in peace or violence, with affection or hostility, cooperation or fights, and satisfaction or disappointment.

Abstrak: Akblak dan tingkah laku manusia terbentuk melalui konstruksi sosial, dan dapat dibangun melalui pendidikan. Artikel ini bertujuan untuk. menjelaskan interaksi di kelas, berdasarkan pandangan teori pembelajaran konstruktifistik, sebagai sumber terciptanya atmosfir positif yang sangat penting bagi pembentukan akblak. Akblak bukanlab sekedar diajarkan atau disisipkan dalam sejumlab materi kewarganegaraan atau pengetabuan sosial, tetapi harus dikembangkan dalam berbagai kegiatan di kelas. Menurut teori ini, membangun atmosfir yang baik dan tepat adalah sangat penting untuke memperkenalkan nilai-nilai yang baik di mana siswa belajar mengkonstruksi pengetahuannya sendiri melalui interaksi yang terus menerus dengan lingkungannya. Mereka dapat belajar tentang kebidupan dan memahami bagaimana masyarakat bidup dan dalam kondisi apa mereka bidup, apakah dalam damai atau kekerasan, kasih sayang atau permusuban, kerja sama atau perkelahian, dan kepuasan atau kekecewaan.

Keywords: interaksi, suasana sosial, emosi, pendidikan akblak. 
DI RUANG kelas sering ditemukan perilaku dominatif atau integratif antara guru dan peserta didik di kelas. Perilaku dominatif di kelas menandakan peran guru yang otoriter dalam pembelajaran dan perilaku integratif menandakan peran guru sebagai fasilitator dan mediator di kelas. Kedua bentuk perilaku antara guru dan peserta didik ini mencerminkan suasana kelas yang memiliki kaitan dengan struktur dalam kelas dan kebutuhan murid akan kepribadian, dan ketiga-tiganya itu mempengaruhi tingkah laku dalam kelas, termasuk belajar.

Misalnya, lingkungan belajar dimana anggota kelas tidak mempedulikan apa yang dilakukan oleh kelas mencerminkan suasana kelas apatis dan akan membentuk sikap apatis peserta didik. Jika keputusan kelas cenderung ditetapkan oleh peserta didik, akan tercipta suasana demokratis yang dapat membentuk perilaku peserta didik yang saling menghargai, menjunjung tinggi perbedaan dan sikap toleran. Jika peserta didik di kelas sering bertindak keributan, tidak tertib, dan berbuat gaduh, kelas akan merefleksikan suasana kekacauan. dan masih banyak lagi suasana sosial di kelas yang menunjukkan kecenderungan akan kepribadian peserta didik.

Suasana sosial di kelas yang kurang baik bisa diubah dan dibentuk menjadi baik bila diinginkan. Sebaliknya, bila iklim kelas yang positif tidak dijaga dan dipertahankan keberadaannya maka akan berubah menjadi iklim yang jelek.

Interaksi di kelas adalah sumber dari berbagai suasana sosial di kelas, baik itu suasana sosial yang negatif maupun suasana sosial yang positif. Interaksi antara guru dan murid berlandaskan pada motif, keinginan, kepentingan, kebutuhan, dan orientasi sendiri tentang berbagai macam hal berkaitan dengan pendidikan.

Berbagai teori memberikan pandangan yang berbeda-beda tentang pengembangan interaksi di kelas untuk mengkondisikan suasana sosial yang baik dan dikehendaki bersama karena suasana sosial yang terkendali dan positif akan mempengaruhi kepribadian yang baik. Sebaliknya, suasana sosial yang buruk akan mempengaruhi kepribadian yang buruk. Misalnya, teori Behaviorisme memandang pembentukan karakter atau kepribadian akan terjadi dengan memberikan stimulus sebanyak- 
banyak kepada siswa dan siswa diharapkan memberikan respons. Kepribadian dan karakter seseorang dapat terbentuk melalui kontinuitas stimulus dan respons. Sedangkan teori konstruktivistik memandang bahwa kepribadian atau akhlak seseorang terbentuk melalui relasi interpersonal yang disertai dengan konstruksi diri dan pengetahuan. Teori konstruktivis telah memberikan berbagai pandangan bagai mana interaksi di kelas dapat menciptakan suasana sosial yang mandiri, aktif, dan bertanggung jawab dari peserta didik. Jika relasi interpersonal yang positif terjadi berulang-ulang dan terus menerus dipertahankan oleh guru dengan berbagai perannya yang menfasilitasi dan memediasi lingkungan belajar di kelas, peserta didik dapat dikondisikan dan dibiasakan dengan perilaku yang baik dan positif. Perilaku baik dan positif yang terjadi secara berulang-ulang dalam diri peserta didik akan membentuk karakter yang kuat.

\section{Akhlak, Etika, Moral, dan Karakter}

Kata "Akhlak" berasal dari bahasa Arab, jamak dari khuluqun (خلق) yang menurut bahasa berarti budi pekerti, perangai, tingkah laku atau tabiat. Ibnu Miskawaih, sebagaimana dikutip A. Mustofa, memberikan definisi sebagai berikut :

$$
\text { حال للنفس داعية لها الى افعالها من غير فكر وروية }
$$

Artinya: keadaan jiwa seseorang yang mendorongnya untuk melakukan perbuatan-perbuatan tanpa melalui pertimbangan perkiraan (lebih dahulu).

Imam al-Ghazali, dikutip oleh A. Mustofa, mengemukakan definisi akhlak sebagai berikut:

$$
\text { الخلق عبارة عن هيئة في النفس راسخة عنها تصـدر الأفعال بسهولة ويسر من غير حاجـة }
$$

Artinya: akhlak ialah sesuatu sifat yang tertanam dalam jiwa yang daripadanya timbul perbuatan-perbuatan dengan mudah, dengan tidak memerlukan pertimbangan pikiran (lebih dahulu). ${ }^{1}$

${ }^{1}$ A. Mustofa, Akhlak Tasawuf(Bandung: Pustaka Setia, 2008), 11-2 
Akhlak baik adalah al-khuluq dan al-khalq (akhlak) adalah dua ungkapan yang sama-sama sering digunakan. Yang dimaksud dengan khalq adalah bentuk lahir, sedangkan yang dimaksud dengan khuluq adalah bentuk batin.

Akhlak adalah cermin hati yang paling dalam. Dari hati tersebut lahir perbuatan-perbuatan yang sangat mudah, tanpa membutuhkan pemikiran dan pandangan. Jika hati melahirkan perbuatan indah dan terpuji - baik menurut akal atau agamadisebut dengan akhlak baik. Dan jika hati melahirkan perbuatan buruk disebut dengan akhlak buruk. ${ }^{2}$

Selain akhlak, dikenal istilah moral. Adapun arti moral dari segi bahasa berasal dari bahasa latin, mores yaitu jamak dari kata mos yang berarti adat kebiasaan. ${ }^{3}$ Selanjutnya moral dalam arti istilah adalah suatu istilah yang digunakan untuk menentukan batas-batas dari sifat, perangai, kehendak, pendapat atau perbuatan yang secara layak dapat dikatakan benar, salah, baik, atau buruk. Namun, antara etika dan moral memiliki perbedaan. Dalam pembicaraan, etika untuk menentukan nilai perbuatan manusia baik atau buruk menggunakan tolok ukur yang digunakan adalah norma-norma yang tumbuh dan berkembang dan berlangsung di masyarakat, yaitu adat-istiadat, kebiasaan dan lainnya yang berlaku di masyarakat.

Etika dan moral memiliki arti yang sama tetapi dalam pemakainnya sehari-hari ada sedikit perbedaan. Moral atau moralitas dipakai untuk perbuatan yang sedang dinilai, sedangkan etika dipakai untuk pengkajian sistem nilai yang ada.

Secara bahasa, etika diartikan ilmu pengetahuan tentang asas-asas akhlak. ${ }^{4}$ Dari segi istilah telah dikemukakan para ahli dengan ungkapan yang berbeda-beda sesuai dengan sudut pandangnya. Ahmad Amin misalnya mengartikan etika sebagai ilmu yang menjelaskan arti baik dan buruk. ${ }^{5} \mathrm{Ki}$ Hajar Dewantara

${ }^{2}$ Adnan Tharsyah, .Manusia yang Dicintai dan Dibenci Allab (Bandung: Mizan Pustakam, 2008), 109.

${ }^{3}$ Asmaran As., Pengantar Studi Akblak (Jakarta: Rajawali Pers, 1992), 8.

${ }^{4}$ W.J.S. Poerwadarmionta, Kamus Umum Bahasa Indonesia (Jakarta: Balai Pustaka, 1991), 278.

${ }^{5}$ Ahmad Amin, Etika (Ilmu Akblak), ter. Farid Ma'ruf dari judul asli, alAkblaq (Jakarta: Bulan Bintang, 1983), 3. 
mendefinisikan etika sebagai ilmu yang mempelajari soal kebaikan (dan keburukan) teristimewa yang mengenai gerakgerik pikiran dan rasa yang dapat merupakan pertimbangan dan perasaan sampai mengenai tujuannya yang dapat merupakan perbuatan. $^{6}$

Etika dinyatakan sebagai filsafat moral, yaitu studi yang sistematik mengenai sifat dasar dari konsep-konsep nilai baik, buruk, harus, benar, salah dan sebagainya. Dari beberapa definisi etika tersebut di atas dapat diketahui, bahwa etika berhubungan dengan empat hal, yakni: pertama, dilihat dari segi obyek pembahasannya, etika berupaya membahas perbuatan yang dilakukan oleh manusia. Kedua, dilihat dari segi sumbernya, etika bersumber pada akal pikiran atau filsafat. Ketiga, dilihat dari segi fungsinya, etika berfungsi sebagai penilai, penentu, dan penetap terhadap suatu perbuatan yang dilakukan oleh mausia. Dengan demikian etika lebih berperan sebagai konseptor terhadap sejumlah prilaku yang dilaksanakan oleh manusia yang berkaitan dengan nilai-nilai untuk digunakan dalam menentukan posisi atau status perbuatan yang dilakukan manusia. Dengan demikian etika sifatnya humanistis dan antroposentris, yakni berdasar pada pemikiran manusia dan diarahkan pada manusia. Dengan kata lain etika adalah aturan atau pola tingkah laku yang dihasilkan oleh akal manusia. ${ }^{7}$

Selain moral dan akhlak juga dikenal istilah karakter. Menurut Koesoema, karakter dianggap sama dengan kepribadian, yaitu ciri atau sifat khas dari seseorang yang bersumber dari lingkungan dan bawaan sejak lahir. ${ }^{8}$

Istilah akhlak, moral, dan karakter memiliki arti yang sama yaitu menunjukkan tingkah laku individu yang membentuk kepribadian. Berbagai negara menggunakan istilah yang berbedabeda dalam hal pendidikan perilaku dan kepribadian. Di Amerika istilah pendidikan karakter lebih popular saat ini. Dua dekade yang lalu istilah yang lebih popular adalah pendidikan

'Ki Hajar Dewantara, Bagian Pertama Pendidikan, (Yogyakarta: Taman Siswa, 1966), 183.

7Abuddin Nata, Akblak Tasawuf, (Radja Grafindo Persada, 2010), 89-92.

${ }^{8}$ Doni A. Koesoema, Pendidikan Karakter: Strategi Mendidik Anak di Zaman Global (Jakarta: Grasindo, 2010), 80. 
moral, yang banyak dirujuk oleh masyarakat Asia. Sebagian masyarakat Jepang menggunakan istilah "moralogy". Di Inggris lebih memilih istiah "pendidikan nilai" dalam kurikulum dan pendidikan. Namun demikian, istilah pendidikan moral di Amerika memiliki kedekatan dengan kelompok liberal, konstruktivis, dan kognitivis. Sedangkan kelompok tradisional, konservatif, dan behaviouris lebih memilih istilah pendidikan karakter. ${ }^{9}$

\section{Internalisasi Nilai: Fungsi Emosi dalam Pembentukan Akhlak}

Jiwa adalah sisi psikis manusia yang memiliki nilai dan kadar kemanusiaan yang mempengaruhi tingkah laku manusia. Al-nafs dengan berbagai maknanya yang kesemuanya merupakan informasi berharga untuk memperoleh kejelasan tentang bagai mana pembentukan tingkah laku manusia yang akhirnya menjadi wujud akhlak atau karakter manusia.

Dalam al-Qur'an dijelaskan bahwa al-nafs dipersiapkan untuk dapat menampung dan mendorong menusia melakukan perbuatan baik dan buruk. Dalam Surat al-Shams ayat 7-8 dijelaskan "Demi jiwa serta penyempurnaan (ciptaannya). Maka Dia mengilhamkan kepadanya (jalan) kejahatan dan ketakwaan."

Akhlak dan jiwa atau nafs adalah dua sisi dalam manusia yang menyatu dan tidak terpisahkan. Oleh karena itu, ketika mendefinisikan akhlak, Ibnu Miskawaih memandang bahwa akhlak adalah kondisi jiwa, yaitu "keadaan jiwa seseorang yang mendorongnya untuk melakukan perbuatan-perbuatan tanpa melalui pertimbangan perkiraan (lebih dahulu)", begitu juga alGhazali. ${ }^{10}$

Jiwa manusia dapat menampung gagasan, pikiran, kemauan (irädab), dan tekad (arm). Dalam firman Allah (Qs. al-Ra'd [13]:13) dijelaskan bahwa suatu kaum tidak akan berubah keadaannya sebelum mereka mengubah terlebih dahulu apa yang ada di dalam nafs mereka.

'Marvin W. Berkowitz "The Scien of Character Education" dalam William Damon Bringing in a New Era in Character Education (California: Hoover Institution Press, 2002), 44.

${ }^{10}$ Mustofa. Akblak..., 11-2. 
Akhlak terpuji maupun tercela tidak terbentuk secara instan dan tiba-tiba seperti benda yang muncul dari langit atau keluar dari bumi. Namun, akhlak dan tingkah laku manusia terbentuk melalui proses konstruksi sosial dengan melibatkan proses internalisasi, obyektifikasi, dan eksternalisasi.

Akhlak terpuji merupakan hasil obyektifikasi dari berbagai interaksi sosial yang ditindaklanjuti dengan internalisasi kegiatan interpersonal yang dipandang baik, benar, efektif, dan efisien. Obyektifikasi adalah proses menangkap makna dari obyek melalui indera sensorik yang dalam psikologi dikenal dengan proses sensasi. Makna-makna dari obyek kemudian diolah melalui daya 'aql11 yang bisa disebut dengan persepsi. Persepsi adalah interpretasi terhadap hal-hal yang ditangkap indera sensorik.

Proses perseptual kemudian dilanjutkan dengan proses internalisasi. Internalisasi akan menghasilkan penghayatan dalam diri individu dengan menjadikan sesuatu yang dikenal dan dipahami sebagai bagian dari diri sendiri. Kesadaran ini karena individu telah memahami realitas obyektif menjadi realitas subyektif. Proses internalisasi terjadi melalui aktivitas qalb12 karena qalb memiliki fungsi emosi melalui kerja dhawq seperti merasakan kesedihan, kebahagiaan, cinta, dan sebagainya. Proses emosi dhawq merupakan upaya memberikan feedback terhadap sensasi melalui persepsi. Proses dhawq mampu melahirkan

11 'Aql memiliki aneka makna, di antaranya bermakna al-hijr atau al-nuhā yang berarti kecerdasan. Sedangkan kata kerja (fi'il) 'aqala bermakna habasa yang berarti mengikat atau menawan. Menurut Baharuddi, orang yang menggunakan akalnya pada dasarnya adalah orang yang mampu mengikat hawa nafsunya, sehingga hawa nafsunya tidak dapat menguasai dirinya. Ia mampu mengendalikan dirinya terhadap dorongan nafsu dan juga dapat memahami kebenaran agama. Lihat Baharuddin, Paradiqma Psikologi Islami: Studi tentang Elemen Psikologi dalam Al-Qur'an (Yogyakarta: Pustaka Pelajar, 2004), 14.

${ }^{12}$ Qalb adalah masdar dari kata qalaba yang berarti berubah, berpindah, dan berbalik.Imam al-Ghazali membedakan qalb sebagai organ fisik yang berarti jantung dan sebagai dimensi jiwa yang bersifat ruhaniyah yang memiliki kemampuan menangkap pengetahuan yang berhubungan dengan mengingat dan berpikir tentang Allah.Al-Qur'an mengisyaratkan bahwa qalb memiliki kemampuan penghayatan dan perasaan takut, gelisah, harapan, rindu, cinta, dan ketenangan. Qalb memiliki fungsi rasional dan emosional. 
ekspresi yang disertai gerak sensoris seperti mengeluarkan air mata jika sedih atau tersenyum jika bahagia, dan wajah muram jika berduka.

Agar dhawq terus menerus aktif dan merefleksikan perilaku secara kreatif, kunci utamanya adalah dengan meluaskan ruang horisontal dhawq dengan berempati terhadap sesama. Dengan merasakan apa yang tengah dirasakan orang lain, akan terjadi proses pengkayaan intuitif. Sedangkan secara vertikal agar dhawq terus terasa, hendaknya menghidupkan "rasa bersamaNya" Dengan demikian, akan menghindarkan dirinya dari sikap sombong, angkuh, perasaan sok kuat, sok kuasa, sok pintar, dan sok benar sendiri. ${ }^{13}$

Selain dhawq proses emosi juga terjadi dalam sadr. Hasil kerja dhawq dan sadr akan menghasilkan kesadaran moral atau disebut conscensience, conscientia, gewissen, geweten. Kesadaran moral akan ditransformasikan dalam wujud perilaku dan tindakan yang disebut dengan eksternalisasi.

Namun demikian, tindakan tidak muncul secara spontan terkadang melalui proses dilematis karena qalb harus dihadapkan pada pilihan-pilihan yang pelik sehingga terjadi konflik batin. Tindakan bisa dibedakan pada tindakan berbasis emosi emotion based action dan tindakan berbasis pemecahan masalah atau problem based action. Tindakan berbasis emosi muncul karena emosi yang tersentuh, seperti karena belas kasihan, rasa sayang, cinta, atau karena benci.

Tindakan berbasis pemecahan masalah adalah tindakan yang melalui proses emosi, rasionalisasi, dan dhikr. Problem based action membutuhkan bantuan fu'ad dan lub. Fu'ad ${ }^{14}$ adalah hati nurani yang membantu memberikan informasi dalam bentuk 42-3.

${ }^{13}$ Ilung S. Enha, LQ Eleven Pillars of Intelligence (Sidoarjo: ADEC, 2013),

${ }^{14} F u$ 'ad berasal dari kata $f$ a $d$ yang berarti gerak. Secara leksikal $f u$ 'ad sinonim dengan jantung. Fu'ad memiliki tugas memberikan informasiinformasi penting bagi jiwa. Informasi-informasi pentng itu bisa bersumber dari sisi luar jiwa, seperti yang disampaikan oleh penglihatan dan pendengaran. Sebagian informasi mengendap di ruang dhawq dan membekas di ruang sadr. Tugas fu'ad senantiasa bergerak untuk mendapatkan informasi dari kedua ruang tersebut. Dalam al-Qur'an fu'ad sering dihubungkan dengan inderawi yang bersifat fisik. 
pengalaman-pengalaman emosi yang tersimpan dalam dhawq dan sadr.

Sedangkan lubb adalah kemampuan jiwa tingkat tinggi dan paling sempurna yang berada dalam qalb yang paling dalam. Untuk meraih kecerdasan lubb dibutuhkan kerja keras tidak cukup dengan perangkat ilmu pengetahuan yang luas atau perenungan yang mendalam, tetapi juga melalui ibadah ritual, ketahanan mentalitas, kedewasaan sikap, kesempurnaan budi serta kelembutan moral.

Berikut ini, sekema fungsi emosi dari kalbu yang menghasilkan tingkah laku:

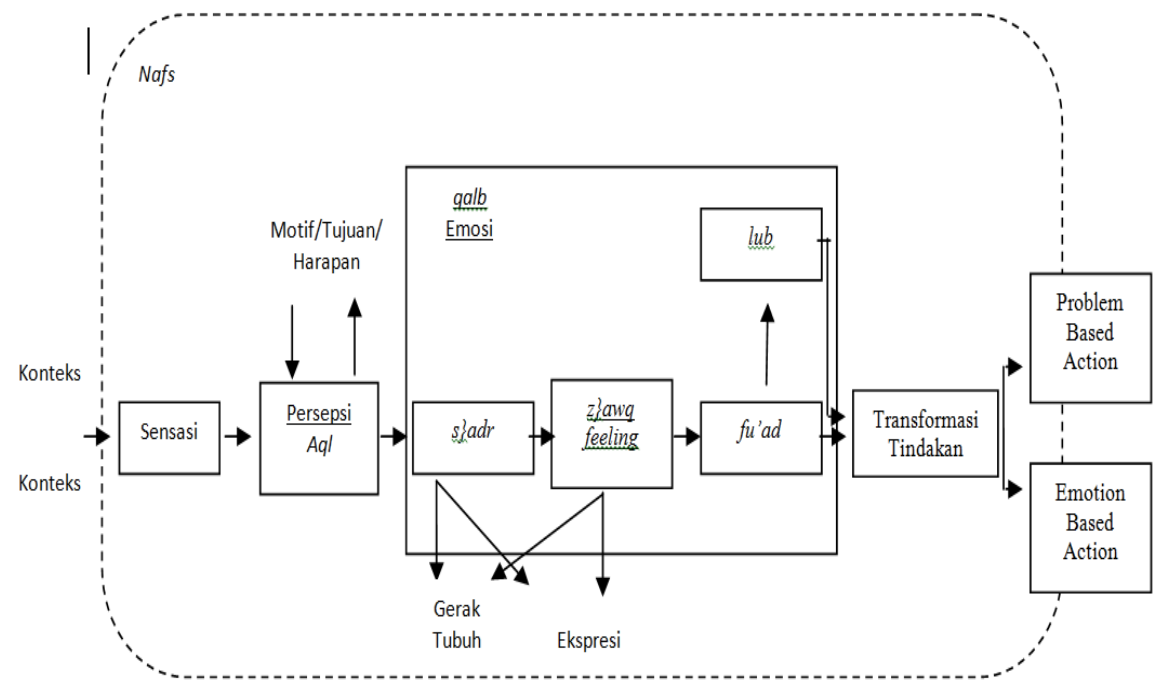

Skema Fungsi emosi atau kalbu yang menghasilkan tingkah laku

Dalam dunia pendidikan dan pengajaran, pendidik memiliki tugas mencetak peserta didik yang cerdas dan berakhlak mulia atau smart and good. Mencetak siswa yang berakhlak baik tidak cukup hanya dengan mengajarkan ilmu tentang baik dan buruk tetapi juga membiasakan dan mengasah kalbu mereka agar memiliki jiwa yang suci dan bersih tazkiyah al-nafs. ${ }^{15}$ Emosi yang ada dalam hati ibaratnya seperti cermin. Cermin akan bersih dan bercahaya bila dibersihkan sehingga mampu menangkap gambar yang ada didepannya. Sebaliknya, jika cermin kotor gambarnya

${ }^{15}$ Syekh Khalid bin Abdurrahman Al-'Akk, Cara Islam Mendidik Anak (Yogyakarta: Ad-Dawa', 2006), 242 
tidak jelas karena tidak mampu menangkap gambar di depannya. Jalan yang dapat mensucikan hati adalah dengan mendekatkan diri kepada Allah sedekat-dekatnya melalui jalan spiritualitas.

Seperti halnya cermin secara perlahan-lahan dari individu terefleksi sesuatu yang bersifat eksternal. Eksternalisasi terhadap berbagai kegiatan interpersonal ini mengkristal secara perlahan sehingga terbentuk sebagai sesuatu yang bersifat eksternal, umum, dan memaksa sebagai fakta sosial. ${ }^{16}$

\section{Fungsi Kelas dalam Pengembangan Akhlak}

Kelas di mana terjadi proses belajar mengajar telah menghadirkan ribuan interaksi setiap harinya. Interaksi oleh Damsar diartikan sebagai suatu tindakan timbal balik antara dua orang atau lebih melalui suatu kontak atau komunikasi. ${ }^{17}$ Hubungan antara guru dan siswa di kelas merupakan sistem interaksi karena sifat interaksinya yang saling ketergantungan satu sama lain secara teratur dan menyeluruh. Selain itu, interaksi di kelas juga bersifat sosial sehingga kelas juga disebut sistem sosial. Telaah ahli sosiologi pendidikan yang mendekati ruang kelas adalah yang ditulis oleh Parsons, "The school class as a social system". ${ }^{18}$ Di sini, Parsons menyajikan suatu penjajakan fungsifungsi ruang kelas. ${ }^{19}$

Hubungan guru dan siswa di kelas terkait dengan ikatan moral. Hubungan guru dan murid berlandaskan pada motif, keinginan, kepentingan, kebutuhan, dan orientasi sendiri tentang berbagai macam hal berkaitan dengan pendidikan. Mereka secara individual memberikan sinyal, tanda, persepsi, sikap, dan tindakan tentang sesuatu yang berkaitan dengan keberadaan hubungan mereka.

Hubungan guru dan murid berisi "kesepakatan", seperti tentang disiplin, kebersihan, kerapihan, tanggung jawab dalam melaksanakan tugas-tugas di sekolah atau di rumah, dan berbagai

16Damsar, Pengantar Sosiologi Pendidikan, (Jakarta: Kencana, 2011), 112.

${ }^{17}$ Ibid., 98.

18"The School Class as a Social System" adalah artikel dalam bunga rampai Hasley, Floud dan Anderson. Lihat, Philip Robinson, Beberapa Perspektif Sosiologi Pendidikan (Jakarta: Rajawali Pers, 1986).

${ }^{19}$ Ibid. 
kegiatan pembelajaran lainnya. Kelas merupakan sistem yang ditandai dengan kedekatan fisik anak-anak selama masa-masa tertentu yang cukup lama dan diatur dengan pola otoritas dan jadwal kegiatan yang relatif baku, yang masing-masing memiliki aturan sendiri. Selama beberapa tahun yang lalu para ahli sosiologi telah mengembangkan model-model yang lebih rumit yang memberikan definisi dan menjelaskan aspek-aspek penting struktur dan interaksi dalam kelas.

Menurut Jackson, sebagaimana dikutip Sanapiah Faisal, kelas dalam beberapa hal bisa dipersamakan dengan kerumunan orang yang di dalamnya berjejal-jejal individu. Karena inilah, guru tampaknya terpacu dengan disiplin dan kontrol. Dengan disiplin dan kontrol, murid tidak bertindak semena-mena. Ruang kelas bisa mengalami kekacauan dan tidak tertib. Jika kekacauan dan keributan dibiarkan terus menerus akan tercipta atmosfir kelas yang mengkondisikan siswa melakukan perilaku kurang terpuji. Jika perilaku yang mengacaukan ketertiban dan kedisiplinan kelas terus berlangsung dapat membentuk perangai siswa yang tidak disiplin dan tidak patuh pada aturan sehingga membentuk akhlak tidak baik.

Akhlak terpuji maupun tercela merupakan hasil obyektifikasi dari berbagai interaksi sosial yang ditindaklanjuti dengan internalisasi kegiatan interpersonal yang dipandang baik, benar, efektif, dan efisien. Internalisasi akan menghasilkan penghayatan dalam diri individu dengan menjadikan sesuatu yang dikenal dan dipahami sebagai bagian dari diri sendiri. Kesadaran ini karena individu telah memahami realitas obyektif menjadi realitas subyektif.

Kesadaran moral ini didasarkan atas nilai-nilai yang benarbenar esensial, fundamental. Kesadaran moral itu mencakup tiga hal yaitu: pertama, perasaan wajib atau keharusan untuk melakukan tindakan yang bermoral. Perasaan ini telah ada dalam setiap hati nurani manusia, siapapun, dimanapun dan kapan pun. Kewajiban tersebut tidak dapat ditawar-tawar, karena sebagai kewajiban maka andaikata dalam pelaksanaannya tidak dipatuhi berarti suatu pelanggaran moral.

Adanya perasaan wajib ini menunjukkan bahwa suara batin harus selalu ditaati, karena suara batin justru sebagai kesadaran 
bahwa seseorang merasa mempunyai kewajiban mutlak, untuk melaksanakan sesuatu, tidak ada kekuatan apapun yang berhak mengganggu atau menghalangi pelaksanaannya. orang yang memiliki kesadaran moral dalam bentuk perasaan wajib tersebut akan senantiasa mau berusaha menegakkan kebenaran, kejujuran, keadilan, dan kesamaan, walaupun tidak ada orang lain yang menyuruhnya. Perasaan tersebut demikian kuat, sehingga ia siap menghadapi siapa saja yang coba-coba menghalanginya.

Kedua, kesadaran moral dapat juga berwujud rasional dan obyektif, yaitu suatu perbuatan yang secara universal, artinya dapat disetujui, berlaku pada setiap waktu dan tempat bagi setiap orang yang berada dalam situasi yang sejenis. Dalam masalah rasionalitas kesadaran moral itu, manusia meyakini bahwa akan sampai pada pendapat yang sama sebagai suatu masalah moral, dengan ketentuan manusia tersebut bebas dari paksaan dan tekanan, tidak mencari keuntungan sendiri, tidak berpihak, bersedia untuk bertindak sesuai dengan kaidah yang berlaku umum, pengetahuan jernih dan pengetahuan yang berdasarkan informasi yang obyektif.

Ketiga, kesadaran moral dapat pula muncul dalam bentuk kebebasan. Atas kesadaran moralnya seseorang bebas untuk mentaatinya. Bebas dalam menentukan perilakunya dan di dalam penentuan itu sekaligus terpampang nilai manusia itu sendiri. ${ }^{20}$

\section{Teori Belajar Konstruktivisme}

Teori kontruktivisme dikembangkan oleh Piaget dan Vigotsky. Kedua aliran ini sama-sama menekankan interaksi sosial. Teori belajar konstruktivistik berpandangan bahwa manusia mengkonstruksi pengetahuannya sendiri. Pandangan ini berarti bahwa pengetahuan bukanlah suatu yang bersifat eksternal yang perlu diinternalisasi oleh siswa dan pengetahuan juga bukan sesuatu yang bersifat bawaan. Lebih jauh, para ahli konstruktivistik berpendapat bahwa siswa yang sedang berkembang itu mengkonstruksi pengetahuannya sendiri melalui interaksi yang terus-menerus dengan alam lingkungannya. ${ }^{21}$

${ }^{20}$ Nata, Akblak..., 95

${ }^{21}$ John W. Santrock, Psikologi Pendidikani, ter. Tri Wibowo dari Educational Psychology (Jakarta: Kencana, 2007), 389. 
Konstruktivisme yang dikembangkan Piaget menekankan pada proses intra individual dalam pengkonstruksian pengetahuan. Piaget berkeyakinan bahwa anak belajar melalui interaksi dengan orang dan benda-benda atau obyek-obyek yang ada disekitarnya. Ketika anak berinteraksi, mereka membentuk pemahaman bagaimana keduanya, yaitu dunia atau lingkungan dan orang berinteraksi. Pada saat anak-anak dihadapkan pada ide-ide yang mungkin tidak sesuai atau tidak cocok dengan pemahamannya, mereka mulai mengadaptasi ide-ide itu ke dalam pemahaman barunya. Konstruktivistik memandang proses perubahan dan adaptasi itu sebagai belajar.

Menurut Piaget pengalaman pendidikan harus dibangun di seputar struktur kognisi pembelajar. Pendidikan yang optimal membutuhkan pengalaman yang menantang bagi si pembelajar sehingga penyusunan pengetahuan oleh siswa dapat menghasilkan pertumbuhan intelektual. Untuk menciptakan jenis pengalaman ini, guru harus tahu level fungsi struktur kognisi.

Konstruktivisme yang dikembangkan Vigotsky memfokuskan pada konstruksi pengetahuan secara inter individual. Pengetahuan dikonstruksi secara kolaboratif antara individu yang selanjutnya keadaan tersebut dapat disesuaikan oleh setiap individu.

Vigotsky mengemukakan empat prinsip pembelajaran konstruktivistik, yaitu:

1. Pembelajaran sosial (social learning) di mana siswa belajar melalui interaksi bersama dengan orang dewasa atau teman yang lebih cakap

2. Zone of proximal development, yaitu siswa akan mempelajari konsep-konsep dengan baik dan siswa dapat memecahkan masalah yang lebih tinggi tingkat kerumitannya dibanding perkembangan kognitif anak dengan bantuan orang dewasa atau temannya

3. Cognitif apprenticeship, suatu proses yang menjadikan siswa sedikit demi sedikit memperoleh kecakapan intelektual melalui interaksi dengan orang yang lebih ahli, orang dewasa, atau teman yang lebih cakap. 
4. Pembelajaran termediasi yang disebut Vigotsky dengan scaffolding. Siswa diberi masalah yang kompleks, sulit, dan realistic dan kemudian diberi bantuan dalam memecahkan masalah siswa.

Vigotsky menekankan interaksi antara aspek internal dan eksternal dari pembelajaran dan penekanannya pada lingkungan sosial pembelajaran di mana fungsi kognitif manusia berasal dari interaksi sosial masing-masing individu dalam konteks budaya. Menurut konstruktivism sosial, siswa akan mengalami belajar saat siswa bekerja menangani tugas-tugas yang belum dipelajari namun tugas-tugas tersebut masih dalam jangkauan kemampuannya.

\section{Implikasi Pembelajaran Konstruktivistik terhadap Suasana Sosial di Kelas}

Istilah yang digunakan oleh ahli sosiologi untuk menjelaskan seluruh kualitas sosial suatu kelompok atau lembaga adalah suasana sosial (social climate). Konsepsi suasana sosial beranjak dari asumsi bahwa suasana dalam kelas memiliki pengaruh penting pada sikap dan penampilan murid. Ciri-ciri penting kelas sebagai lingkungan belajar bisa dijelaskan dari segi perpaduan sikap dan tingkah laku individu selaku pembentuk kelas. Ukuran suasana sosial dalam kelas telah dikembangkan sekarang ini dan sebagian berhasil mencakup seluruh kompleksitas dalam kelas atau bahkan aspek-aspeknya yang terpenting.

Suasana sosial yang positif merupakan suatu kondisi dimana keadaan atau sekolah dan lingkungannya dalam keadaan yang sangat aman, damai, dan menyenangkan untuk kegiatan belajar mengajar jauh dari keributan, kekacauan, dan keruwetan.

Menurut Sergiovanni, sebagaimana dikutip Moedjiarto, iklim sekolah merupakan energi yang terdapat di dalam organisasi yang dapat memberikan pengaruhnya terhadap sekolah, tergantung bagaimana energi tersebut disalurkan dan diarahkan. Sedangkan menurut Larsen, seperti dikutip oleh Moedjiarto, iklim sekolah adalah suatu norma, harapan, dan kepercayaan dari personil-personil yang terlibat dalam organisasi sekolah yang 
dapat memberikan dorongan untuk melakukan tindakan yang mengarah pada prestasi siswa yang tinggi. ${ }^{22}$

Suasana sosial baik di kelas maupun di lingkup sekolah berasal dari relasi interpersonal. Relasi interpersonal merupakan konteks bagi peserta didik untuk mengkonstruk diri Suasana sosial akan mewarnai setiap aspek dari perkembangan peserta didik. Suasana sosial merupakan konteks di mana anak-anak mengkonstruk ide dan perasaan tentang masyarakat dan bendabenda. Dari suasana sosial anak-anak belajar kehidupan dan bagaimana masyarakat hidup dengan aman atau tidak, penuh kasih sayang atau permusuhan, kerja sama atau perkelahian, dan mendapatkan kepuasan atau kekecewaan. Dari konteks aktivitas interpersonal, peserta didik merefleksi dirinya dengan karakteristik tertentu, seperti jujur, santun, menghargai, menghormati atau sebaliknya. Mereka belajar dari relasi sosial melalui eksplorasi, coba-coba, atau menemukan. Anak-anak mengkonstruk keseluruhan kepribadian dari orang dewasa atau teman sejawat mereka dengan segenap pikiran, perasaan, dan nilai-nilai.

De Vries dan Betty Zan mengemukakan cara pengorganisasian kelas untuk menumbuhkan moral atau pembentukan akhlak terpuji di kelas. Pembentukan moral atau ahlak di kelas harus dimulai dari sikap guru yang menghargai peserta didik, memiliki daya tarik bagi mereka, perasaan, ide, dan nilai-nilai. Berikut ini cara mengorganisasikan kelas dengan berbagai aktivitas dan interaksi antara siswa dan guru di kelas: ${ }^{23}$

1. Mengorganisasikan kebutuhan peserta didik, seperti kebutuhan psikologis, kebutuhan emosional, dan kebutuhan intelektual

2. Mengorganisasikan interaksi sejawat. Anak-anak membutuhkan aktivitas termasuk kebutuhan berinteraksi guru konstruktivis akan menciptakan interaksi sejawat dengan mengorganisasikan berbagai program di kelas

22Moedjiarto, Sekolah Unggul: Metodologi untuk Meningkatkan Mutu Pendidikan (Jakarta: Duta Graha Pustaka, 2001), 28-30.

${ }^{23}$ Rheta De Vries dan Betty Zan, Moral Classrooms, Moral Children: Creating a Constructivist Atmosphere in Early Education, (London: Teachers College Press, 1994), 58-61. 
sehingga relasi interpersonal terjadi secara natural, seperti bekerja sama melalui bermain kelompok, diskusi kelompok, dan kegiatan lainnya dimana peserta didik saling bertanya, mengemukakan pendapat, dan bertukar gagasan.

3. Mengorganisasikan tanggung jawab peserta didik di kelas. Ketika peserta didik sudah merasa memiliki kelas mereka, tahap berikutnya yang harus diperhatikan guru konstruktivis adalah rasa tanggung jawab terhadap kelas. Bagaimana jika ruang kelas tidak tertib, maka mereka harus menyadari kewajiban mereka untuk menciptakan kedisiplinan dan ketertiban di kelas. Bagai mana jika ruang kelas kotor dan berantakan sehingga mengganggu pembelajaran. Maka mereka harus memiliki kesadaran bersama dalam menjaga kebersihan, memelihara ketertiban sehingga mereka dapat belajar dengan tenang, nyaman, dan menyenangkan.

Suasana sosial di kelas atau sekolah dapat diciptakan dan dibentuk. Artinya, Iklim kelas yang kurang baik bisa diubah dan dibentuk menjadi baik bila diinginkan. Sebaliknya, bila iklim kelas yang positif tidak dijaga dan dipertahankan keberadaannya maka akan berubah menjadi iklim yang jelek. Iklim kelas atau sekolah mengalami perubahan secara berangsur-angsur dan tidak terasakan. Oleh karena itu, guru harus memperhatikan juga berbagai kegiatan di kelas, seperti:

1. Kegiatan yang menumbuhkan minat belajar siswa. Minat siswa merujuk pada kecenderungan emosional yang positif dari peserta didik. Minat merupakan jantung dari konstruktivisme. Baik Dewey maupun Piaget menegaskan agar guru memulai dari kekuatan peserta didik untuk aktif. Dengan cara apa agar peserta didik menjadi aktif dalam pembelajaran di kelas? Jawabannya adalah dengan memotivasi mereka aktif secara mental melalui aktivitas fisik atau berfikir. Pembelajaran aktif di kelas tidak akan terjadi jika peserta didik secara terisolasi dari teman lainnya.

2. Mengkondisikan kegiatan eksperimen di kelas. Kegiatan eksperimen akan mengajak peserta didik aktif dalam pembelajaran. Mereka mengamati, memperhatikan temuantemuan dalam kesperimen, bertanya, dan membuat komentar terhadap temuan eksperimen sehingga suasana 
sosial di kelas akan diwarnai rasa ingin tahu, antusias dalam pembelajaran, termotivasi, dan interest terhadap pembelajaran.

3. Mengkondisikan kerjasama dalam pembelajaran. Guru membantu merancang tugas yang mendorong peserta didik untuk mencari pemecahan masalah secara kolektif sehingga meningkatkan kepercayaan diri yang tinggi dalam mengembangkan pengetahuan dan rasa tanggungjawab pribadi.

Mengapa suasana sosial sangat penting dalam pembentukan akhlak peserta didik? Nilai dan pendidikan akhlak bukanlah bahan ajar biasa yang tertuang pada pokok bahasan seperti dalam mata pelajaran agama, PKn, IPS, atau Pendidikan Akhlak, tetapi harus dikembangkan dalam berbagai kegiatan di kelas, dikondisikan dalam berbagai lingkungan belajar, dan diintegrasikan pada seluruh mata pelajaran. Oleh karena itu, guru dituntut mengembangkan suasana sosial untuk memperkenalkan nilai-nilai budaya dan karakter bangsa.

\section{Catatan Akhir}

Kepribadian atau akhlak peserta didik di kelas terbentuk melalui interaksi di kelas yang dapat mempengaruhi suasana sosial di kelas. Interaksi antara aspek internal dan eksternal dari pembelajaran serta lingkungan sosial di kelas merupakan sumber fungsi kognitif dan perkembangan sosio-moral peserta didik di kelas. Dalam aliran kostruktivisme, pembelajaran bukanlah seperti mengisi air dalam botol dimana guru dianggap seseorang yang mahatahu dan siswa belum tahu, yang harus diberi tahu. Dalam proses belajar, siswa aktif mencari tahu dengan membentuk pengetahuannya, sedangkan guru membantu agar pencarian itu berjalan baik.

Relasi antara guru dan peserta didik di kelas merefleksikan ribuan interaksi di kelas yang menggambarkan suasana sosial. Menurut teori konstruktivis, relasi interpersonal merupakan konteks bagi peserta didik untuk mengkonstruk diri. Suasana sosial akan mewarnai setiap aspek dari perkembangan peserta didik. Suasana sosial merupakan konteks di mana anak-anak mengkonstruk ide dan perasaan tentang masyarakat dan benda- 
benda yang terjadi secara terus menerus sehingga dapat membentuk kepribadian. Wa al-Lāh a lam bi al-sawāb.

\section{Daftar Pustaka}

Nata, Abuddin. 2010. Akblak Tasawuf. Radja Grafindo Persada. Tharsyah, Adnan. 2008. Manusia yang Dicintai dan Dibenci Allah. Bandung: Mizan Pustaka.

Amin, Ahmad. 1983. Etika (Ilmu Akblak). ter. Farid Ma'ruf dari judul asli, Al-Akblaq. Jakarta: Bulan Bintang.

al-'Akk, Syekh Khalid bin Abdurrahman. 2006. Cara Islam Mendidik Anak. Jogjakarta: Ad-Dawa'.

Asmaran As. 1992. Pengantar Studi Akblak. Jakarta: Rajawali Pers. Baharuddin. 2004. Paradiqma Psikologi Islami: Studi tentang Elemen Psikologi dalam Al-Qur an. Yogyakarta: Pustaka Pelajar.

Berkowitz, Marvin W. "The Scien of Character Education" dalam William Damon Bringing in a New Era in Character Education, California: Hoover Institution Press.

Damsar. 2011. Pengantar Sosiologi Pendidikan. Jakarta: Kencana.

Dewantara, Ki Hajar. 1996. Bagian Pertama Pendidikan.

Yogyakarta: Taman Siswa.

Enha, Ilung S. 2013. LQ Eleven Pillars of Intelligence, Sidoarjo: ADEC.

Mustofa, A. 2008. Akblak Tasawnf. Bandung: Pustaka Setia.

Koesoema, A. Doni. 2010. Pendidikan Karakter: Strategi Mendidik Anak di Zaman Global. Jakarta: Grasindo.

Moedjiarto. 2001. Sekolah Unggul: Metodologi untuk Meningkatkan Mutu Pendidikan, Jakarta: Duta Graha Pustaka.

Poerwadarmionta,W.J.S. 1991. Kamus Umum Bahasa Indonesia. Jakarta Balai Pustaka, 1991.

Robinson, Philip. 1986. Beberapa Perspektif Sosiologi Pendidikan, Jakarta: Rajawali Pers.

Santrock, John W. 2007. Psikologi Pendidikani, ter. Tri Wibowo dari Educational Psychology. Jakarta: Kencana.

De Vries, Rheta dan Betty Zan. 1994. Moral Classrooms, Moral Children: Creating a Constructivist Atmosphere in Early Education. London: Teachers College Press. 